\title{
INOVASI DAN DIVERSIFIKASI PRODUK USAHA BERBAHAN SPIRULINA DI KECAMATAN TAWANGSARI KABUPATEN SUKOHARJO
}

\author{
Anif Nur Artanti $^{1 *}$, Fea Prihapsara ${ }^{2}$ \\ ${ }^{1}$ Program Studi D3 Farmasi, Universitas Sebelas Maret Surakarta \\ ${ }^{2}$ Program Studi S1 Farmasi, Universitas Sebelas Maret Surakarta \\ Jalan Ir. Sutami Nomor 36 A, Kota Surakarta, Jawa Tengah 57126 \\ *)alamat korespondensi: anif.apt@staff.uns.ac.id
}

\begin{abstract}
ABSTRAK
Serbuk kering spirulina yang berasal dari Spirulina platensis memiliki banyak kandungan bahan aktif yang memiliki kemampuan untuk meningkatkan sistem kekebalan tubuh melalui mekanisme antioksidan, antiinflamasi dan neuro protective. Selama ini untuk memenuhi kebutuhan sebagai bahan obat tradisional dan kosmetik, spirulina merupakan salah satu bahan baku obat impor, karena produksinya masih jarang ada di Indonesia. Berada di Kecamatan Tawangsari, Kabupaten Sukoharjo terdapat usaha produksi spirulina dibawah pengelolaan UKM Neoalgae. Namun pengolahan hasil produksi masih berupa serbuk spirulina. Dalam kegiatan pengabdian ini akan dilakukan pengembangan usaha spirulina menjadi produk healing oil yang bermanfaat sebagai cairan obat luar untuk mengatasi jerawat, bisul dan penyakit kulit lainnya. Metode kegiatan berawal dari sosialisasi program, pelatihan produksi dan pembukuan keuangan kepada karyawan di kedua UKM serta pendaftaran produk untuk memperoleh ijin edar. Bekerjasama dengan UKM Andromeda, formulasi dan produksi healing oil ini dilakukan dengan memberdayakan masyarakat sekitar. Hasil yang diperoleh berupa produk healing oil berbahan spirulina yang sedang dalam proses pengurusan ijin edar di BPOM. Kegiatan pengabdian masyarakat yang dilakukan untuk membuat sediaan healing oil dengan menggunakan bahan spirulina telah dijalankan dengan baik. Melalui kegiatan pengabdian ini diharapkan dapat memberikan alternatif usaha perekonomian baru di masyarakat.
\end{abstract}

Kata kunci : diversifikasi, healing oil, kabupaten sukoharho, spirulina

\section{PENDAHULUAN}

Spirulina

mengandung beberapa vitamin, seperti vitamin $B$, vitamin $E$, Vitamin $\mathrm{K}$, phenolic acids, tocopherols, $g$ - linolenic acid, asam folat; pigmen, seperti $b$-carotenes, chlorophyll $a$ dan pigmen phycocyanin; serta mineral, terutama zat besi. Spirulina mempunyai fungsi sebagai antioksidan, antiviral, 
imunomodulator, mampu mengobati dislipidemia, meningkatkan hemoglobin, leukosit dan trombosit serta mampu menstimulasi stem sel di sumsum tulang. Spirulina mengandung tinggi protein $(60 \%-70$ $\%$ dari berat kering). Spirulina juga mengandung asam amino essensial seperti leucine (10.9\%), valine (7.5\%), dan isoleucine (6.8\%) (Sanchez, dkk., 2003). Di antara makanan, spirulina mengandung tinggi provitamin $A$ ( $\beta$ carotene) dan B12. Spirulina mengandung $4 \%-7 \%$ lipid (linoleic acid (LA) dan $\gamma$-linolenic acid). Kandungan mineral yang dikandung terbanyak spirulina adalah besi (60\%) di mana lebih mudah diserap daripada ferrous sulfate (Sanchez dkk, 2003).

Bahan baku spirulina saat ini sebagian masih diimpor dari China dan India. Unit Kegiatan Masyarakat (UKM) Neoalgae merupakan salah satu UKM lokal yang memproduksi spirulina (Huzain, 2017). Bekerjasama dengan Universitas Sebelas Maret, melalui kegiatan ini UKM Neoalgae Indonesia Makmur dan UKM Andromeda memproduksi produk healing oil berbasis bahan baku spirulina. Kapasitas produksi serbuk spirulina yang dihasilkan mencapai $200 \mathrm{~kg} /$ bulan. Bahan serbuk inilah yang kemudian akan diproses untuk memperoleh healing oil sekaligus merupakan upaya diversifikasi produk yang dilakukan oleh PT Neoalgae. Memasuki era globalisasi, maka mau tidak mau UKM harus mampu bersaing dengan perusahaan besar. Melihat kondisi tersebut, maka diperlukan suatu terobosan untuk melakukan pengembangan dan peningkatan kapasitas produksi UKM salah satunya adalah melalui diversifikasi produk spirulina yang berupa sediaan healing oil di CV Andromeda. Gambaran kondisi saat ini dari UKM Mitra dapat ditunjukkan pada Gambar 1 berikut.

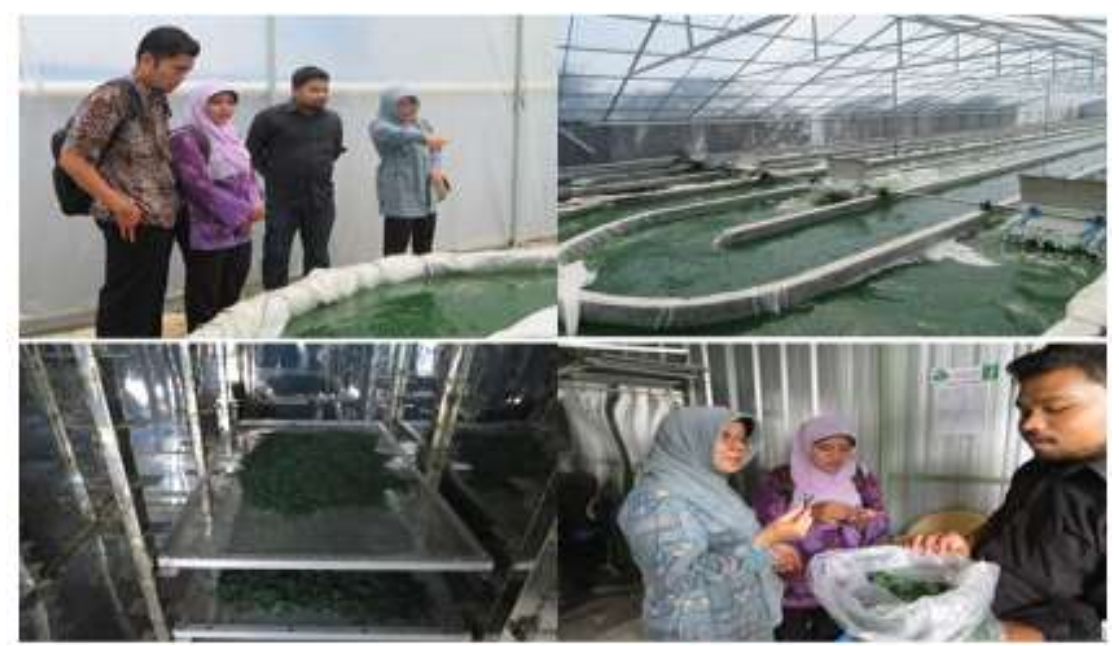

Gambar 1. Lokasi produksi serbuk spirulina di PT Neoalgae Indonesia Makmur berupa kolam kultivasi spirulina, pengeringan spirulina hingga menjadi serbuk. 
Tujuan umum kegiatan ini diharapkan dapat memberikan output antara lain:

1. Terjaminnya kualitas hasil produksi healing oil sebagai bahan kosmetik hasil diverifikasi produk spirulina.

2. Dengan menggandeng UKM Mitra diharapkan produk hasil olahan spirulina yang diproduksi memiliki legalitas dan izin edar resmi dari DepKes dan BPOM.

3. Menjadi komoditas ekonomi baru masyarakat.

Tujuan khusus kegiatan ini diharapkan dapat memberikan output antara lain :

1. UKM mampu melakukan manajemen pembukuan keuangan secara mandiri.

2. UKM memiliki sistem administrasi serta tata kelola yang jelas dalam produksi dan pemasaran healing oil.

UKM mampu melakukan analisis kelayakan usaha pengolahan pico oil untuk mendapatkan gambaran besarnya investasi dan biaya yang harus dikeluarkan dalam membangun usaha pengolahan serta besarnya manfaat yang dapat diperoleh oleh stakeholder dari usaha ini.Program pengolahan spirulina menjadi sediaan healing oil dilakukan melalui 1) Transfer teknologi dalam pengolahan spirulina menjadi formulasi sediaan healing oil, 2) Produksi healing oil yang diharapkan menjadi komoditi ekonomi masyarakat, 3) Pemasaran produk dan aspek manajemen pengolahan healing oil melalui UKM Neoalgae serta 4) Analisa kelayakan usaha produksi healing oil. Melalui kegiatan ini akan dilakukan pengembangan teknologi dalam pengolahan pasca panen spirulina menjadi produk ekonomi berupa healing oil dengan menambahkan carrier oil yakni minyak nyamplung. Minyak dan resin nyamplung yang bermanfaaat sebagai bahan baku pembuatan bahan dasar obat tradisional sehingga bersifat sinergis jika digunakan sebagai carrier oil pichosianin. Sediaan healing oil ini diharapkan dapat memberikan alternatif usaha perekonomian baru di masyarakat.

\section{METODE KEGIATAN}

Metode pelaksanaan IbM untuk produksi healing oil sebagai inovasi produk berbahan baku spirulina akan direalisasikan dengan mekanisme, meliputi 1) aspek produksi healing oil sebagai inovasi produk berbahan baku spirulina dengan beberapa tahapan, yaitu : sosialisasi program ; pelatihan teknologi pembuatan healing oil berbasis spirulina ; praktek pembuatan healing oil berbasis spirulina dan aplikasi metode mikroenkapsulasi untuk memperoleh healing oil berbasis spirulina, untuk selanjutnya dapat diformulasikan dengn harga jual dengan packing yang berkualitas. 2) aspek legalitas: produk healing oil berbahan baku spirulina ini didaftarkan izin edarnya ke BPOM sebagai produk obat tradisional (OT). Kegiatan utama adalah transfer teknologi pembuatan 
healing oil berbasis spirulina untuk meningkatkan kapasitas produksinya sebagai bahan obat tradisional. Pelatihan akan diikuti praktek pembuatan healing oil berbasis spirulina oleh masing-masing kelompok UKM. Pelatihan akan diadakan selama 2 bulan berturutturut. Praktek secara mandiri oleh kelompok UKM akan didampingi oleh Tim Pelaksana dan dilakukan untuk meningkatkan ketrampilan praktis para anggota UKM Mitra. Sebagai kegiatan akhir, akan dilakukan analisis usaha produksi healing oil berbasis spirulina untuk menghitung Break Even Point (BEP) dari usaha produksi minyak herbal berbasis nyamplung.

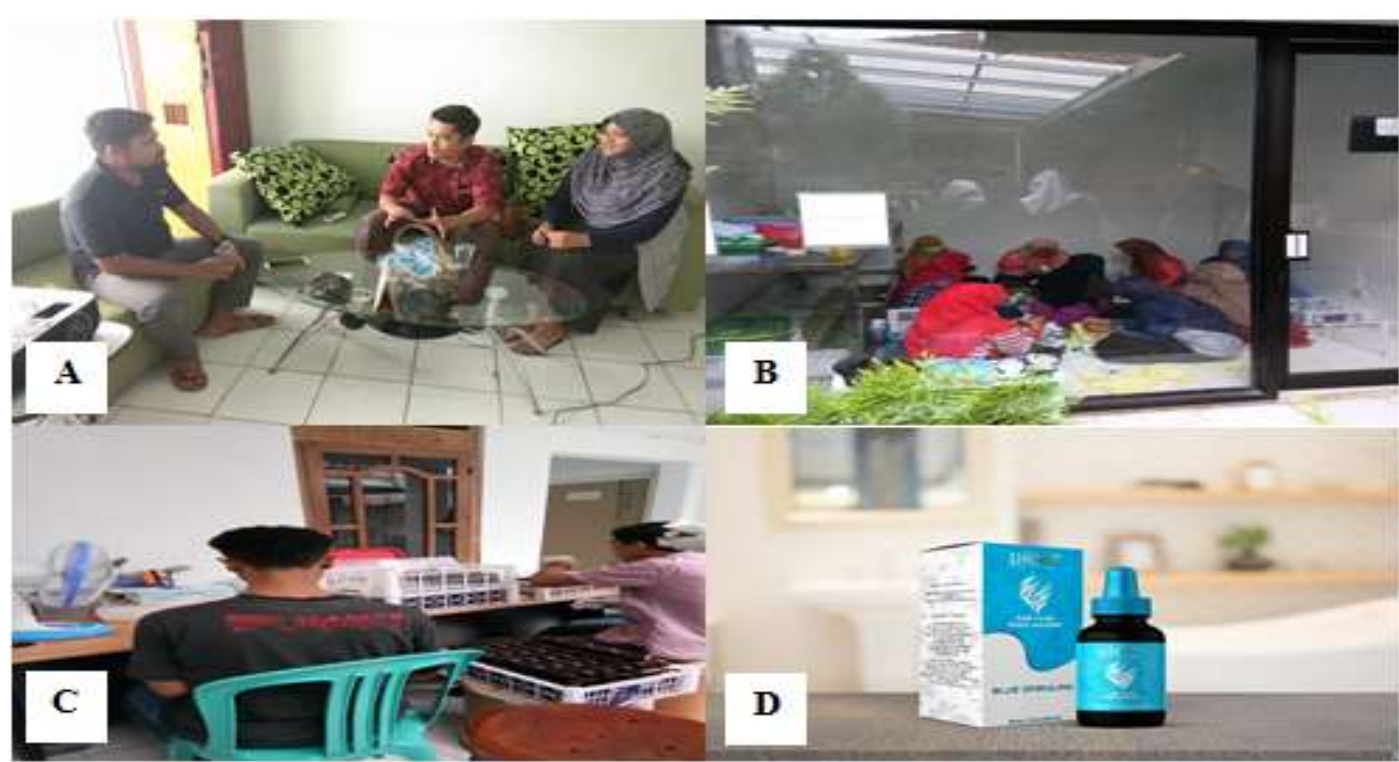

Gambar 2. Tahapan kegiatan Pengabdian masyarakat. (A) Sosialisasi dan Pelaksanaan IbM (B) Penjelasan kepada mitra mengenai kegiatan yang akan dilakukan di UKM mitra dalam pembutan dan produksi healing oil dan Pplatihan produksi di UKM Mitra (C) Pengemasan sediaan healing oil yang dilakukan di UKM mitra (D) produk sediaan healing oil yang didaftarkan melalui BPOM 


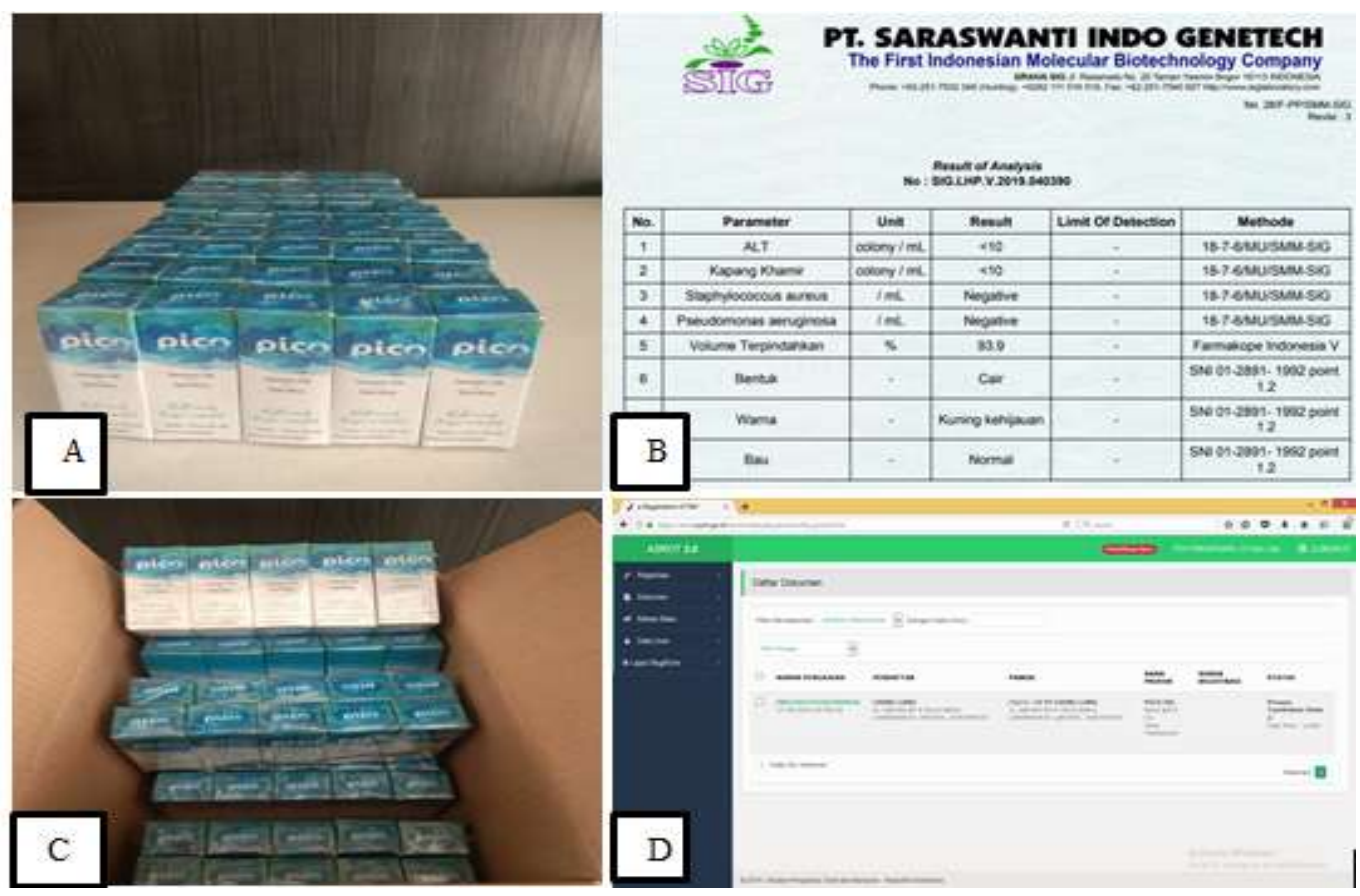

Gambar 3. Hasil kegiatan Pengabdian masyarakat. (A) Produk healing oil berbahan spirulina (B) Hasil pengujian kualitas produk sesuai standar yang dipersyaratkan BPPOM (C) Pengemasan tersier sediaan healing oil yang dilakukan di UKM mitra (D) bukti daftar produk healing oil yang telah didaftarkan melalui BPOM

Salah satu hasil luaran yang diperoleh dari hasil kegiatan pengabdian masyarakat adalah berupa produk pico oil yang saat ini sudah masuk dalam proses untuk mendapatkan ijin edar dari BPOM. Secara kuantitas, terdapat peningkatan jumlah penggunaan spirulina dengan peningkatan produksi sebanyak $10 \%$ dari produksi awal (Gambar 3). Meskipun pelaksanaan kegiatan pengabdian masyarakat ini sudah terlaksana sesuai jadwal yang telah ditentukan dalam perencanaan program, akan tetapi tim pengabdian masyarakat secara berkesinambungan membina dalam produksi dan pembuatan produk healing oil di UKM mitra. Spirulina yang digunakan sebagai bahan baku dalam pembuatan healing oil diperoleh dari UKM Neoalgae sementara formulasi pembuatan healing oil dilakukan di UKM Andromeda. Pembinaan dilakukan secara bertahap dengan melakukan langkah perbaikan sistem untuk memenuhi aturan persyaratan produk obat tradisional sebagaimana yang telah ditetapkan oleh Badan 
POM yaitu bebas cemaran dan memnuhi syarat sanitasi higiene ( BPOM, 2014) sehingga diharapkan akan menghasilkan produk healing oil yang tetap aman dan memiliki stabilitas yang baik dalam penyimpanan sehingga dapat diterima dan digunakan di masyarakat (BPOM, 2005). Pembinaan secara berkesinambungan yang dilakukan oleh tim pengabdian dilakukan melalui konsultasi langsung dengan karyawan UKM melalui pelatihan dalam formulasi sediaan maupun dalam proses pendaftaran produk tersebut untuk mendapatkan legalitas ijin edar dengan mendaftarkan produk secara online melalui sistem asrot BPOM (BPOM, 2012). Alur pendaftaran secara online melalui BPOM memerlukan data hasil uji kualitas produk berupa data bebas cemaran mikroba yang dilihat dari parameter nilai Angka Lempeng Total (ALT) dan Angka Kapang Khamir (AKK) (BPOM, 2011) Pengabdian masyarakat yang dilakukan di kedua UKM mitra memberikan dampak dan perubahan khusunya dalam pengembagan produk dan pemasaran produk healing oil. Perubahan kegiatan yang terjadi setelah dilakukan kegiatan pengabdian masyarakat adalah :

1. Permasalahan mitra UKM yang dihadapi semula adalah belum optimalnya pemanfaatan hasil ekstraksi spirulina sehingga dengan adanya kegiatan pengabdian masyarakat ini akan meningkatkan pemanfaatan spirulina untuk diformulasi menjadi sediaan healing oil yang bermanfaat sebagai obat tradisional.

2. Belum adanya produk sediaan yang dibuat dari bahan spirulina sehingga setelah dilakukan kegiatan pengabdian masyarakat ini akan dihasilkan produk sediaan healing oil dari bahan spirulina

3. UKM mitra belum banyak memperoleh informasi mengenai picosianin atau senyawa aktif yang terkandung dalam spirulina sehingga melalui kegian pengabdian ini dapat dikembangkan metode ekatraksi spirulina untuk memperoleh kadar picosianin yang optimal.

4. Produksi spirulina awalnya hanya sebatas uji coba dan belum dilakukan untuk skala produksi, sehingga melalui kegiatan pengabdian masyarakat ini produksi spirulina dapat dilakukan secara berkelanjutan dengan kapasitas produksi meningkat.

5. UKM mitra sebelumnya tidak pernah memperoleh pelatihan pembuatan sediaan obat tradisional yang berbahan spirulina sehingga setelah kegiatan pengabdian masyarakat ini karyawan yang bekerja di UKM mitra dapat mengembangkan produk sediaan berbasis spirulina. 
6. Permasalahan yang sebelumnya ditemukan di lapangan adalah belum adanya sistem pembukuan sederhana terkait dengan sistem manajemen dan administrasi produk spirulina sehingga setelah dilakuakan pengabdian masyarakat ini para karyawan mampu membuat sistem pembukuan terkait dengan sistem manajemen dan administrasi.

\section{KESIMPULAN DAN SARAN}

Kegiatan pengabdian

masyarakat yang dilakukan untuk membuat sediaan healing oil dengan menggunakan bahan spirulina yang diproduksi di Kecamatan Tawangsari Kabupaten Sukoharjo telah dijalankan dengan baik dan sesuai dengan tujuan pelaksanaan kegiatan. Kualitas hasil produksi produk healing oil sebagai bahan kosmetik hasil diverifikasi produk spirulina memnuhi persyaratan di BPOM untuk memperoleh nomor ijin edar. UKM mitra dapat melakukan manajemen pembukuan keuangan secara mandiri sehingga pengelolaan administrasi lebih baik dari sebelumnya. Kerjasama yang baik antara tim pengabdian masyarakat dan mitra pengabdian masyarakat dapat berlanjut sehingga produk healing oil dapat menjadi komoditi ekonomi baru di masyarakat.

\section{UCAPAN TERIMA KASIH}

Terimakasih

kepada

Universitas Sebelas Maret atas Dana Hibah PNBP 2019 skim Program Kemitraan Mayarakat.

\section{DAFTAR PUSTAKA}

Badan Pengawas Obat dan Makanan, 2005, Pedoman Cara Pembuatan Obat Traidisional yang Baik, BPOM RI: Jakarta.

Badan Pengawas Obat dan Makanan, 2014, Persyaratan Mutu Obat Tradisional, BPOM RI: Jakarta.

Badan Pengawas Obat dan Makanan, 2011, Kriteria dan Tata Laksanan Registrasi Obat, BPOM RI: Jakarta.

Badan Pengawas Obat dan Makanan, 2012, Petunjuk Operasional sebagai Pedoman Cara Pembuatan Obat Traidisional yang Baik, BPOM RI: Jakarta.

Huzain ML. 2017, Profil PT Neoalgae Indonesia Makmur, Interview, Sukoharjo.

Sanchez M, Castillo JB, Rozo C, Rodriguez I. 2003. Spirulina (Arthrospira): An edible microorganism. A review, Universitas Scientarium 8(1) : 724. 